\title{
Strategies at SD Muhammadiyah 3 Pandaan in Optimizing Al-Islamic Learning and Kemuhammadiyahan During the Covid-19 Pandemic [Strategi SD Muhammadiyah 3 Pandaan dalam Mengoptimalkan Pembelajaran Al-Islam dan Kemuhammadiyahan di Tengah Pandemi Covid-19]
}

\author{
Ovi Shinta Asri*, Muhlasin Amrullah \\ \{ Ovishinta9511@gmail.com,muhlasin@umsida.ac.id \} \\ Fakultas Psikologi dan Ilmu Pendidikan,Universitas Muhammadiyah Sidoarjo, Indonesia
}

\begin{abstract}
This study was conducted to determine the Al-Islam and Kemuhammadiyahan learning strategies in the midst of the COVID-19 pandemic situation which required online learning. In collecting data for this scientific work using methods in the form of interviews and observations during the research process. This study aims to find out how the strategies applied by SD Muhammadiyah 3 Pandaan in learning Al-Islam and Kemuhammadiyahan during online learning take place. The results show that in implementing learning strategies in the midst of a pandemic, SD Muhammadiyah 3 Pandaan school provides fun online learning that does not pressure students so that students feel happy in learning. In learning Al-Islam and Kemuhammadiyahan SD Muhammadiyah 3 Pandaan managed to package memorable online learning by utilizing technological advances such as learning through live streaming, google meet, and learning videos. In the teaching and learning process of Al-Islam and Kemuhammadiyahan learning, the school, especially Al-Islam and Kemuhammadiyahan teachers, also applies rote learning as well as Al-Islam and Kemuhammadiyahan learning when the learning is face to face directly. The difference is when online learning is for memorizing students learn and submit their assignments in the form of videos that are sent to the teacher. The results of the study, Al-Islam and Kemuhammadiyahan teachers more often apply learning through videos containing subject matter so that students can access it freely without being bound by time. The success of online learning at SD Muhammadiyah 3 Pandaan is due to the role of teachers and students who can support each other for communication to continue so that there is reciprocity in the learning process even though distance learning.
\end{abstract}

Keywords: Online Learning, Strategy, Technology.

\begin{abstract}
Abstrak. Penelitian bertujuan untuk mengetahui strategi pembelajaran Al-Islam dan Kemuhammadiyahan di tengah situasi pandemi covid-19 yang mengharuskan untuk pembelajaran daring. Dalam pengumpulan data untuk karya ilmiah ini menggunakan metode berupa wawancara dan observasi saat proses penelitian. Penelitian ini bertujuan untuk mengetahui bagaimana strategi yang diterapkan SD Muhammadiyah 3 Pandaan dalam pembelajaran Al-Islam dan Kemuhammadiyahan selama pembelajaran daring berlangsung. Hasil menunjukkan dalam menerapkan strategi pembelajaran di tengah pandemi, sekolah SD Muhammadiyah 3 Pandaan memberikan pembelajaran daring yang menyenangkan tidak menekan siswa sehingga siswa merasa senang dalam belajar. Dalam pembelajaran Al-Islam dan Kemuhammadiyahan SD Muhammadiyah 3 Pandaan berhasil
\end{abstract}




\begin{abstract}
mengemas pembelajaran daring yang berkesan dengan memanfaatkan kemajuan tekonologi seperti pembelajaran melalui live streaming, google meet, dan vidio pembelajaran. Dalam proses belajar mengajar pembelajaran Al-Islam dan Kemuhammadiyahan, pihak sekolah terutama guru Al-Islam dan Kemuhammadiyahan juga menerapkan pembelajaran hafalan selayaknya pembelajaran Al-Islam dan Kemuhammadiyahan jika saat pembelajaran tatap muka secara langsung. Perbedaanya saat pembelajaran daring untuk hafalan siswa mempelajari dan menyetorkan tugasnya melalui bentuk vidio yang dikirim kepada guru. Hasil dari penelitian, guru Al-Islam dan Kemuhammadiyahan lebih sering menerapkan pembelajaran melalui vidio-vidio yang berisi materi pelajaran agar siswa dapat mengaksesnya dengan leluasa tidak terikat waktu. Dalam keberhasilan pembelajaran daring SD Muhammadiyah 3 Pandaan karena peran guru dan siswa yang dapat saling mendukung untuk komunikasi tetap berjalan sehingga adanya timbal balik dalam proses pembelajaran meskipun pembelajaran jarak jauh.
\end{abstract}

Kata Kunci: Pembelajaran Daring, Strategi, Teknologi

\title{
1. Pendahuluan
}

Peranan pendidikan di zaman modern merupakan salah satu tolak ukur untuk menentukan kemajuan di suatu negara. Menurut Theodore Brameld memaparkan bahwa "Education a power means competent and strong enough to enable us, the majority of people, to decide what kind of a world me wand and how to achieve that kind world. [1] Dalam praktiknya pendidikan identik dengan sekolah yaitu pendidikan formal. Dalam pendidikan formal terdapat guru sebagai peran utama untuk transfer ilmu kepada siswa. Dalam transfer ilmu terdapat materi-materi tiap pelajaran yang diajarkan. Salah satu pelajaran yang diajarkan di sekolah-sekolah dasar yaitu AlIslam dan Kemuhammadiyahan. Dalam undang-undang Republik Indonesia No.20 tahun 2003 tentang Sistem Pendidikan Nasional, bahwa pembelajaran adalah proses interaksi pendidik dengan peserta didik dan sumber belajar yang berlangsung dalam suatu lingkungan belajar. Tujuan Pendidikan Nasional untuk mencerdaskan generasi bangsa yang berasal dari proses interaksi pendidik dengan peserta didik di sekolah-sekolah. Dari interaksi tersebut terdapat kegiatan pembelajaran yang memuat materi-materi pelajaran yang berguna untuk memberikan informasi pengetahuan kepada siswa. Siswa siswi sekolah dasar memerlukan pedoman akhlak dan karakter sesuai dengan ajaran Al-Quran dan as-sunnah. Untuk menanamkan karakter tersebut dapat melalui pembelajaran Al-Islam dan Kemuhammadiyahan. Adanya pembelajaran tersebut diharapkan menciptakan generasi yang unggul dalam ilmu pengetahuan dan karakternya sesuai dengan ajaran agama islam.

Al-Islam dan Kemuhammadiyahan sangat penting untuk diajarkan kepada siswa, bukan hanya sekadar hafalan namun bagaimana menerapkan arti dari ayat-ayat al-qur'an ke dalam kegiatan kehidupan sehari-hari. [2] Dalam penerapan Al-Islam dan Kemuhammadiyahan dapat dimulai dari lingkungan sekolah. Saat di sekolah peserta didik terutama siswa sekolah dasar masih mempunyai rasa suka bermain maka dari itu guru harus bisa menggabungkan bermain dengan belajar agama agar siswa merasa senang dan mudah menerima materi pembelajaran tersebut. Namun, kondisi saat ini dikarenakan ada pandemi covid-19 yang menuntut pembelajaran jarak jauh maka dunia pendidikan merubah strategi pembelajaran agar pembelajaran tetap berlangsung walaupun tidak bisa bertemu atau tatap muka.

Menurut Thorme memaparkan bahwa "pembelajaran daring adalah pembelajaran yang menggunakan teknologi multimedia, kelas virtual, CD ROM, streaming video, pesan suara, email dan telepon konferensi, teks online animasi, dan video streaming online" 
(Kuntarto,2017:102). Dalam keadaan yang memaksa kita tetap berada di rumah namun aktivitas tetap berjalan terutama pendidikan menjadikan kita harus bisa memanfaatkan perkembangan teknologi dengan baik. Pemanfaatan teknologi dalam dunia pendidikan dapat melalui aplikasi dan media apapun tergantung bagaimana kesepakatan guru dan peserta didik untuk mengolah pembelajaran dengan baik. Untuk itu disini penulis akan membahas bagaimana strategi sekolah dasar dalam menyampaikan materi pendidikan agama islam kepada siswa di salah satu SD Muhammadiyah 3 Pandaan.[3] Di tulisnya karya tulis ilmiah ini untuk mengetahui secara mendalam bagaimana strategi SD Muhammadiyah 3 Pandaan dalam pembelajaran jarak jauh terutama pelajaran Al-Islam dan Kemuhammadiyahan mulai dari cara mengajar hingga penilaian saat pembelajaran jarak jauh. Dengan karya tulis ilmiah ini dapat memberikan informas tentang strategi apa saja yang digunakan SD Muhammadiyah 3 Pandaan dalam pembelajaran daring.

\section{Metode Penelitian}

Penelitian ini menggunakan metode penelitian kualitatif deskriptif. Metode deskriptif adalah suatu metode yang digunakan untuk menggambarkan atau menganalisis suatu hasil penelitian tetapi digunakan untuk membuat kesimpulan yang lebih luas (Sugiono, 2005) Pendekatan kualitatif merupakan proses penelitian untuk memahami masalah-masalah sosial atau manusia dengan menganalisis kata-kata untuk menciptakan gambaran kompleks dan menyeluruh, serta melaporkan pandangan informasi terperinci yang diperoleh dari para sumber informasi dalam lingkungan alam. Pendekatan kualitatif juga bertujuan untuk menyelidiki, menemukan menggambarkan serta menjelaskan kualitas atau keistimewaan dari pengaruh sosial yang tidak dapat dijelaskan, diukur, atau digambarkan melalui pendekatan kuantitatif. Teknik pengambilan data dalam penelitian ini melalui wawancara, dokumentasi dan observasi. Adapun trianggulasi yang di pakai dalam penelitian ini adalah trianggulasi teknik. Penggunaan metode kualitatif ini dimaksudkan untuk memperoleh gambaran mengenai strategi pembelajaran AlIslam dan Kemuhammadiyahan di SD Muhammadiyah 3 Pandaan.[4]

\section{Hasil dan Pembahasan}

\subsection{Pembelajaran Daring}

Adanya virus Covid-19 di Indonesia berdampak pada segala sektor baik ekonomi, sosial, pariwisata dan pendidikan. Setelah keluarnya surat edaran Pemerintah pada tanggal 18 Maret 2020 yang menyatakan segala kegiatan di bidang apapun sementara ditunda untuk mengurangi penyebabaran penularan virus corona. Pada tanggal 24 Maret 2020 Menteri Pendidikan dan Kebudayaan Republik Indonesia mengeluarkan Surat Edaran Nomor 4 Tahun 2020 Tentang Pelaksanaan Kebijakan Pendidikan Dalam Masa Darurat Penyebaran Covid-19 yang menjelaskan bahawa proses kegiatan belajar mengajar dilaksanan melalu pembelajaran daring/ jarak jauh di rumah masing-masing. Pembelajaran jarak jauh atau belajar di rumah difokuskan pada pendidikan mengenai pandemi Covid-19 seperti kegiatan yang dilakukan saat pandemi berlangsung dari kebiasaan menjaga kebersihan diri hingga menjaga asupan vitamin.

Pandemi Covid-19 yang sedang terjadi mengharuskan kegiatan belajar mengajar di sekolah secara offline terpaksa dirubah menjadi pembelajaran jarak jauh atau sering disebut pembelajaran daring. Pembelajaran jarak jauh dilakukan sesuai dengan kemampuan sekolah dan kesepakatan dengan wali murid. Pembelajaran jarak jauh menggunakan berbagai aplikasi 
seperti zoom, meet, google classroom, group whatsapp, live streaming dan berbagai vidio di youtube. Dalam pembelajaran jarak jauh, pemberian dan pengumpulan tugas tetap dilakukan untuk penilaian peserta didik. Hal terpenting dalam pembelajaran jarak jauh adalah kesiapan materi dan penyampaian materi yang dapat dipahami dengan baik oleh peserta didik. Komunikasi antara guru dan wali murid harus terjalin intens agar mengetahui setiap perkembangan peserta didik dalam menerima pembelajaran jarak jauh dan dapat dijadikan sebagai bahan evaluasi untuk kegiatan pembelajaran yang lebih baik. [5]

Menurut Isman pembelajaran daring adalah pemanfaatan teknologi jaringan internet untuk kegiatan belajar mengajar. Pembelajaran daring atau online dilaksanakan melalui berbagai aplikasi yang tersedia untuk menunjang pembelajaran berlangsung.[6] Pembelajaran online memiliki kelebihan dan kekurangan dari berbagai sudut pandang orang-orang yang melakukannya. Pembelajaran daring menjadikan guru-guru lebih kreatif untuk memanfaatkan teknologi yang semakin maju guna menciptakan media-media pembelajaran yang menarik untuk peserta didik. Banyak guru-guru yang memanfaatkan tekonologi seperti membuat vidio pembelajaran, mengadakan pembelajaran tatap muka melalui aplikasi berupa zoom atau google meet dan sebagainya. Menurut Heru Purnomo dalam pikiran rakyat memaparkan bahwa "media pemberian tugas di group whatsapp yang dilakukan ketika pembelajaran jarak jauh merupakan penerapan metode yang efektif. Guru-guru sedang menciptakan cara belajar dari rumah yang menyenangkan, ada guru yang menerapkan pembelajaran ceramah seperti di dalam kelas namun dalam konsep online biasanya melalui zoom atau meet, ada guru yang melakukan pembelajaran melalui vidio yang dikirim ke group whatsapp siswa, ada juga guru yang membagikan beberapa vidio dari youtube untuk bahan ajar materi" (Ashari, 2020). Seperti yang dilakukan oleh SD Muhammadiyah 3 Pandaan (MUGA) selama pembelajaran daring berlangsung pihak sekolah terutama guru-guru menciptakan pembelajaran yang bermakna tidak hanya menarik namun siswa dapat memahami dan mengingat materi pelajaran dengan baik.

\subsection{Pembelajaran Daring Al-Islam dan Kemuhammadiyahan}

Menurut Majelis Dikdasmen PP. Muhammadiyah memaparkan bahwa pendidikan Al-Islam dalam Muhammadiyah memiliki peran yang sangat penting, karena dapat dijadikan sarana untuk membina pribadi generasi muda, agar menjadi insan yang beriman dan bertakwa kepada Allah, berakhlak mulia kehidupan sehari-hari sesuai dengan tuntunan al-Qur'an dan Sunnah Rasul. Cara mengembangkan dan menamkan nilai agama dan moral anak usia dini yaitu penanaman karakter melalui pendidikan al-Islam dan Kemuhammadiyahan Fungsi pendidikan kemuhammadiyahan di sekolah muhammadiyah sebagai pembeda dengan sekolah yang bukan milih muhammadiyah. Pembelajaran Al-Islam dan Kemuhammadiyahan menjadi pendidikan karakter bagi anak-anak usia dini. Dengan menanamkan nilai-nilai agama sesuai ajaran islam sejak usia dini akan membentuk karakter yang terpuji dan anak-anak akan terbiasa melakukan segala hal sesuai dengan ajaran agama. Semenjak adanya pandemi covid-19 yang membuat bidang pendidikan tidak dapat berjalan seperti biasanya karena pembatasan tatap muka atau kegiatan secara langsung. Sehingga semua sekolah baik jenjang SD hingga perguruan tinggi menerapkan pembelajaran online.[7]

Pembelajaran online atau sering disebut pembelajaran daring adalah salah satu jembatan yang harus bisa dimanfaatkan dengan baik dalam kondisi pandemi covid-19. dengan adanya pembelajaran daring diharapkan transfer ilmu guru kepada siswanya tetap berlangsung, tidak hanya transfer ilmu tetapi penanaman nilai-nilai karakter juga tetap berjalan. Saat pembelajaran daring berlangsung, guru-guru harus bisa membuat strategi pembelajaran yang menarik minat siswa. Menurut salah satu sejarawan Belanda Linshosten, bahwa anak usia dini hanya bisa 
memfokuskan diri atau belajar secara tersruktur dengan rentang waktu rata-rata 20 menit, Namun jika pembelajaran yang diminati oleh anak, fokus anak akan menjadi lebih dari waktu rata-rata (Anum dkk,2020:1831). Oleh karena itu, guru harus memahami pembelajaran yang baik pada anak usia dini tidak terlalu lama, hanya pada rentang waktu fokus anak. Hal itu dilakukan karena keterbatasan waktu dan tempat untuk bertemu dan pembelajaran yang lebih banyak melalui teknologi akan membuat siswa merasa jenuh dan kurang bebas mengekspresikan dirinya, dengan strategi yang tepat untuk pembelajaran al-islam kemuhammadiyahan diharapkan membuat siswa merasa menikmati pembelajaran daring, dapat menerima materi dengan baik dan dapat mengeluarkan pendapatnya sebagai hasil evaluasi untuk para guru di pembelajaran selanjutnya.

Pembelajaran daring yang memanfaatkan teknologi juga memerlukan berbagai macam strategi, baik strategi untuk pendekatan pembelajaran maupun strategi berjalannya kegiatan belajar mengajar menjadi efektif. Strategi pembelajaran dapat berjalan dengan baik karena adanya kegiatan saling mendukung antara guru dengan siswa. Kegiatan belajar mengajar sekarang ini terhalang oleh jarak, namun komunikan antara guru dengan siswa harus tetap berlajan dengan baik untuk menciptakan ruang belajar yang nyaman dan efektif. Strategi pembelajaran adalah rangkaian cara yang digunakan guru untuk membantu dalam menyampaikan materi pelajaran kepada siswa yang berkaitan dengan berkaitan dengan pemilihan media pembelajaran, pemilihan penilaian, alokasi waktu dan kompetensi yang dapat dikuasai oleh siswa.

\subsection{Sejarah SD Muhammadiyah 3 Pandaan}

SD Muhammadiyah 3 Pandaan merupakan salah satu sekolah dasar islam favorit tertua dikota pandaan. beralamat di J1. Pahlawan Soenaryo No. 256 Kutorejo kecamatan Pandaan, Kabupaten Pasuruan-jawa Timur. Awal mula berdirinya SD Muhammadiyah 3 Pandaan atau lebih sering disebut Muga pada tahun 1962. pada tahun 1962 SD Muga ini berdiri dan bertempat di area masjid Taqwa Pandaan. Seiring berjalannya waktu pada tahun 1969 pindah ke gedung sekolah di daerah Jogosari Pandaan. Pada tahun 2001 SD Muga berpindah tempat lagi di Jl. Pahlawan Sunaryo No. 256 kelurahan Kutorejo Pandaan sampai dengan sekarang, dikarenakan bangunan sd yang lama sudah tidak muat dan lokasi yang sekarang lebih strategis serta lebih luas sehingga SD Muga bisa berkembang pesat dengan baik. SD Muga didirikan oleh pimpinan cabang muhammadiyah (PCM) pandaan untuk sekarang dipimpin oleh Bapak Yus Aminudin. Visi dan misi dari SD Muga sendiri yaitu, Visi Berjiwa Qur'ani, Inspiratif, Terdepan dalam Prestasi. Misi; 1) Hafal Juz Amma; 2) Disiplin Ibadah Melalui Shalat Lima Waktu; 3) Membentuk Karakter Islami; 4) Budaya Baca.

\subsection{Pembelajaran Daring Al-Islam dan Kemuhammadiyahan di SD Muga Pandaan}

Selama pembelajaran daring berlangsung SD Muhammadiyah menerapkan pembelajaran daring pendidikan Al-Islam dan Kemuhammadiyahan dengan memanfaatkan teknologi seperti aplikasi zoom, google meet, group wa dan live streaming. Untuk pembelajaran dari kelas 1 hingga kelas 6 semua rata-rata menggunakan aplikasi google meet. Memang selama pembelajaran daring tidak selalu menggunakan google meet atau zoom untuk melakukan kegiatan belajar mengajar. Menurut Bapak Luqman Wahyudi M.Pd selaku guru Al-Islam dan Kemuhammadiyahan di SD Muhammadiyah 3 Pandaan, untuk kegiatan belajar mengajar juga memanfaatkan vidio pembelajaran. Beliau membuat vidio pembelajaran agar semua siswa dapat mengikuti pelajaran tersebut. Beliau memanfaatkan media vidio pembelajaran karena tidak semua siswa dapat mengikuti live streaming atau zoom yang dilakukan karena kesibukan orang 
tua masing-masing dan kurangnya fasilitas setiap siswa, tidak semua siswa mempunyai handphone sendiri terutama kelas rendah mereka kebanyakan menggunakan handphone orang tua atau kakaknya untuk mengikuti pembelajaran daring.

Dalam pembelajaran daring menuntut guru untuk membuat ide-de kreatif agar menciptakan pelajaran yang bermakna. Dalam artian pelajaran tersebut dapat melekat di ingatan siswa, siswa memahami konsep dasar pelajaran tersebut dan mempunyai kesan menyenangkan dalam proses kegiatan belajar mengajar. Menurut salah satu guru Al-Islam Kemuhammadiyahan SD Muhammadiyah 3 Pandaan Bapak Luqman Wahyudi M.Pd menyampaikan dengan memberikan tugas kepada siswa diharapkan mereka bisa meningkatkan keimanannya kepada Allah SWT sebagai penguasa alam semesta. Seperti contoh saat pembelajaran hafalan asmaul husna Bapak Luqman mengatakan dengan menghafal nama-nama baik Allah SWT akan menjadikan siswasiswi dapat semakin mengenal Allah lebih dekat. Apabila terdapat materi yang tugasnya menghafal biasanya Bapak Luqman selaku guru pendidikan agama islam melakukan murajaah bersama peserta didik melalui vidio, voice note serta google meet.[8]

Dalam pembelajaran Al-Islam dan Kemuhammadiyahan Bapak Luqman memberikan tugas kepada kelas 4 hingga kelas 6 untuk menghafalkan asmaul husna. Bapak Luqman memberikan vidio hafalan melalui youtube sehingga semua siswa bisa mengaksesnya dimanapun dan kapanpun tidak terikat waktu belajar. Siswa diinstruksikan untuk menghafal asmaul husna dengan sering-sering memutar ulang vidio tersebut sehingga pembelajaran yang berlangsung membuat siswa merasa senang. Karena untuk pembelajaran daring yang mengharuskan siswa tetap berada di rumah kadang membuatnya jenuh karena tidak dapat leluasa belajar sambil bermain, tidak bertemu dengan teman-temannya. Maka Bapak Luqman menjadikan pembelajaran melalui vidio ini agar siswa tidak merasa terbebani selama pembelajaran daring dan dapat mengikuti pembelajaran dengan menyenangkan. [9] Untuk pembelajaran Al-Islam dan Kemuhammadiyahan kelas rendah seperti kelas 1 Bapak Luqman memberikan tugas yang menciptakan kekreatifitas siswa namun tidak meninggalkan rasa cinta kepada agama. Seperti tugas membuat kaligrafi sederhana. Bapak Luqman memberikan vidio materi pembelajaran di group whatsapp untuk siswa agar mempelajari materi tersebut dan mengerjakan tugas yang telah diberikan sesuai dengan instruksi. Bapak Luqman membagikan vidio tutorial membuat kaligrafi melalui youtube kemudian siswa mengerjakan tugas tersebut dengan baik. Tujuan dari pembelajaran yang diberikan Bapak Luqman kepada siswanya dengan membuat kaligrafi lafadz Allah diharapkan siswa-siswi bisa menulis lafadz Allah dengan benar, dan yang paling utama adalah penguatan tauhid tentang percaya kepada Allah.

Untuk strategi yang digunakan SD Muhammadiyah 3 Pandaan pada pembelajaran Al-Islam dan Kemuhammadiyahan menurut Bapak Luqman lebih kepada bagaimana menciptakan pembelajaran yang ketuntasan materinya dapat dicapai. Untuk itu selama pembelajaran daring ini sekolah SD Muhammadiyah 3 Pandaan benar-benar memanfaatkan semaksimal mungkin teknologi agar materi pelajaran dapat diterima siswa dengan baik. Menciptakan pembelajaran yang tidak menekan siswa dengan mengajak siswa belajar agama secara menyenangkan melalui vidio-vidio pembelajaran yang dibagikan, melalui live streaming atau bisa dengan pengumpulan tugas-tugas yang menarik membuat bakat dan minat siswa terasah.

\section{Kesimpulan}

Berdasarkan hasil observasi dapat ditarik kesimpulan bahwa pembelajaran daring yang dilakukan oleh SD Muhammadiyah 3 Pandaan berlangsung dengan baik. Untuk pelajaran alislam dan kemuhammadiyahan. Strategi yang diterapkan saat pembelajaran juga berlangsung dengan baik sehingga menjadikan pembelajaran al-islam kemuhammadiyahan menjadi 
pembelajaran yang menyenangkan bukan menekan siswa. Siswa dapat mengikuti pembelajaran al-islam dan kemuhammadiyahan dengan baik dan dapat menuntaskan materi.

\section{Knowledge}

Terselesaikannya karya ilmah ini, penulis mengucapkan terima kasih kepada Allah SWT atas limpahan rahmat dan hidayahnya kepada penulis sehingga dapat menyelesaikan karya ilmiah ini tepat waktu. Bapak Abdul Syukur selaku kepala sekolah SD Muhammadiyah 3 Pandaan yang memberikan izin untuk dapat melakukan observasi di sekolah SD Muhammadiyah 3 Pandaan. Bapak Luqman Wahyudi M.Pd selaku guru Al-Islam dan Kemuhammadiyahan SD Muhammadiyah 3 Pandaan yang bersedia untuk memberikan data-data penelitian melalui wawancara.

\section{References}

[1] Anwar, Muhammad. 2017. Buku Filsafat Pendidikan. Bandung: Kencana.

[2] PWMU.CO.COM. (2020,12 April). Siswa SD Muga Hafalkan Asmaul Husna. Diakses pada 27 April 2021, dari https://penerbitdeepublish.com/cara-menulis-daftar-pustakadari-website/

[3] Aji, Wahyu. 2020. Dampak covid-19 terhadap Implementasi Pembelajaran Daring di Sekolah Dasar. Edukatif : Jurnal Ilmu Pendidikan Volume 2 Nomor 1 April 2020. hal 58

[4] Semiawan, Conny R. 2010. Metode Penelitian Kualitatif. Jakarta: Grasindo

[5] Sunarsi Denok, Danang Kharisma. 2020. Pengembangan Media dan Strategi Pembelajaran Untuk Mengatasi Permasalahan Pembelajaran Jarak Jauh di Pandemi Covid-19. Guru Kita, Vol. 4 No. 3 Juni 2020

[6] Nur, Ani. 2014. Pendidikan Karakter Untuk Siswa SD Dalam Perspektif Islam. Mimbar Sekolah Dasar, Volume 1 Nomor 1 April 2014, hal.53

[7] Nabilah, Ifat, dkk, 2019. Analisis Perkembangan Nilai Agama Moral Siswa Usisa Dasar. Jurnal Pendidikan dan Pembelajaran Dasar, Volume 6 Nomor 2, Desember 2019. hal 194-195

[8] Huda, Hairil, 2019. Membangun Karakter Islami Melalui Al-Islam dan Kemuhammadiyahan (Studi Analisis Perpres Nomer 87 Tahun 2017 tentang Penguatan Pendidikan Karakter (PPK)).TARLIM Jurnal Pendidikan Agama Islam Vol. 2 No. 1 Maret 2019

[9] Setiono Patut, Handayani Etika, Selvia, Widian Wahyu. Strategi Guru dalam Pembelajaran Daring Pada Masa Covid-19 di Sekolah Dasar. Jurnal Riset Pendidikan Dasar Vol. 3, No. 3, Bulan Desember, Tahun 2020 